\title{
Low molecular weight IgM and CD5 B lymphocytes in rheumatoid arthritis
}

Department of Clinical Immunology, Flinders Medical Centre, Flinders University of South Australia, South Australia $\mathrm{H}$ Xu R Geddes P J Roberts-Thomson Correspondence to: A/Professor Peter Roberts-Thomson, Department of Clinical Immunology, Flinders Medical Centre, Bedford Park, SA 5042, Australia. Accepted for publication 7 March 1994

\author{
Huji Xu, Robin Geddes, Peter J Roberts-Thomson
}

\begin{abstract}
Objectives-To evaluate the role of low molecular weight (LMW) IgM and CD5 B cells in rheumatoid arthritis (RA) and to explore the possibility that LMW IgM is derived selectively from this subset of $B$ cells.
\end{abstract}

Methods-LMW IgM in sera and culture supernatants was detected by a sensitive immunoblot technique with an enhanced chemiluminescence detection system. CD5 B cells were determined by FACScan cytometry. In vitro studies were established in culture plates containing pokeweed mitogen with or without 2-mercapatoethanol (2-ME). Supernatants were obtained from CD5 positive hybridomas and CD5 negative hybridomas. Other immunological indices were measured by laser nephelometry.

Results-Circulating LMW IgM was detected in all rheumatoid patients with significantly higher levels being observed in sero-positive patients. LMW IgM correlated significantly with total IgM and RF. Peripheral blood mononuclear cells (PBMC) from the majority of the patients with RA secreted LMW IgM in vitro as did mononuclear cells from a synovial fluid sample. The addition of low concentrations of 2-ME to the culture medium enhanced the proportions of secreted monomeric IgM. In contrast, PBMC from healthy subjects secreted only trace quantities of LMW IgM. In RA no significant correlations were observed between CD5 B cells and LMW IgM and RF. LMW IgM could be detected in the supernatants from both CD5+ and CD5$B$ cell lines. Finally, CD5 B cells were not significantly elevated in RA and levels remained constant over time.

Conclusion-LMW IgM exists in high concentrations in RA sera and synovial fluid. Serum level correlates with RF and IgM. In vitro studies have suggested that the occurrence of LMW IgM may be due to an intrinsic defect(s) in the assembly of the IgM pentameric molecule. LMW IgM is unlikely to be derived solely from CD5 $B$ cells.

(Ann Rheum Dis 1994; 53: 383-390)

Low molecular weight (LMW) $\operatorname{IgM}$ is a naturally occurring monomeric form of circulating IgM. ${ }^{2}$ LMW IgM is found infrequently in healthy adult serum ${ }^{3}$ but has been described in high concentrations in four disease groups: (1) certain autoimmune diseases including rheumatoid arthritis (RA), systemic lupus erythematosus (SLE) and primary biliary cirrhosis; (2) infective diseases such as chronic hepatitis B and subacute sclerosing panencephalitis; (3) immunodeficiency states such as selective IgA deficiency and ataxia telangectasia; and (4) some B cell lymphoproliferative disorders, for example, chronic lymphocytic leukaemia (CLL) and Waldenstrom's macroglobulinaemia. ${ }^{4}$ Previous studies have shown a strong association between the levels of LMW $\operatorname{IgM}$ and the presence of rheumatoid vasculitis in RA and the severity of disease in RA and in SLE. ${ }^{245}$ Furthermore, a significant relationship has also been observed between LMW IgM and the total IgM levels, with levels of rheumatoid factor (RF) and with levels of circulating immune complexes in RA, primary biliary cirrhosis, infective endocarditis, and selective IgA deficiency etc. ${ }^{2-8}$ Its close association with indices of disease severity or activity suggests that LMW IgM may play an important role in the immunopathogenesis of those diseases. However, the functional activity of LMW IgM is poorly understood. Its cellular origins in vivo have not been explored.

The recent discovery that some autoantibodies produced by mice and humans with genetically determined autoimmune disease are derived from $\mathrm{CD} 5 \mathrm{~B}$ cells offers an exciting new avenue for investigation into the pathogenesis of human autoimmune diseases. CD5 B cells are lymphocytes that coexpress a $67-\mathrm{kDa}$ pan $T$ lymphocytes surface glycoprotein, designated $\mathrm{CD} 5$, and surface antigens restricted to the $\mathrm{B}$ lymphocyte lineage. ${ }^{9}$ CD5 B cells exist in varying proportions in discrete locations. ${ }^{9}$ They are present in fetal lymph nodes from 17 weeks of gestation and are also found in the peritoneal and pleural cavities and spleen. ${ }^{9-12} \mathrm{CD} 5 \mathrm{~B}$ cells are relatively abundant in early ontogeny but elevated levels of CD5 B cells have been found in the peripheral blood (PB) of patients with RA, Sjögren's syndrome and other autoimmune diseases. ${ }^{13-16}$ In humans, CD5 B cells constitute a component of the normal human $B$ cell repertoire and are responsible for the production of $\operatorname{IgM}$ antibodies that react with multiple, structurally unrelated antigens, including the $\mathrm{Fc}$ fragment of human IgG (RF) and single stranded DNA. ${ }^{17-20}$ Moreover, it has been shown that $\mathrm{CD} 5 \mathrm{~B}$ cells produces 2 types of RF: (1) a polyreactive and low affinity RF, produced by CD5 $\mathrm{B}$ cells of normal subjects and RA patients; (2) a monoreactive and high affinity RF, which is isolated only by CD5 B 
cells from patients with RA. ${ }^{15}$ These studies therefore suggest CD5 B cells are involved in autoimmune responses. Whether they contribute to the pathogenesis of autoimmune disease is still uncertain.

In this current study we have evaluated the role of LMW IgM and CD5 B cell in RA. We are particularly interested to observe any correlation between these two variables as it is possible that CD5 $\mathrm{B}$ cells may be the cellular origin of LMW IgM in RA.

\section{Materials and methods}

PATIENTS AND CONTROLS

Thirty eight patients with RA participated in the study. All fulfilled the American Rheumatism Association revised criteria for RA, and 31 of the patients were seropositive. There were 27 women and 11 men with a mean (SD) age of $68.3(11.7)$ years and a mean (SD) duration of disease of $13.2(6.3)$ years. Eight patients with other inflammatory arthritides and three patients with osteoarthritis were also studied. Control subjects consisted of 17 healthy adults from the clinical and laboratory staff. Sera and PB from patients and controls were collected at the same time. Synovial fluid (SF) was also collected from one patient with RA.

\section{CELL PREPARATION}

Peripheral blood mononuclear cells (PBMC) and mononuclear cell from SF were separated by Ficoll-Hypaque sedimentation using standard techniques. Ten $\mathrm{mL}$ sample was mixed with $10 \mathrm{~mL}$ phosphate-buffered saline (PBS) and layered slowly onto $10 \mathrm{~mL}$ Lymphoprep (Nyegaard, Oslo). The tubes were then centrifuged at $750 \mathrm{~g}$ for 15 minutes. The mononuclear layer was removed into PBS and washed once. Any remaining red blood cells were lysed by incubating at room temperature for 5 minutes with $5 \mathrm{~mL}$ ammonium chloride lysing solution. The cells were then washed twice with PBS, and resuspended at $10^{7} / \mathrm{mL}$ in RPMI 1640 medium with $10 \%$ fetal calf serum for immunofluorescence staining and in-vitro study.

IMMUNOFLUORESCENCE STAINING CD5 B CELLS Prepared PBMCs were mixed with both $20 \mu \mathrm{l}$ of FITC- anti-CD19 and the $20 \mu \mathrm{l}$ of PElabelled anti-Leu-1 antibody (anti-CD5, Beckton Dickinson) for 30 minutes. In some cases, the cells were first incubated with $50 \mu \mathrm{l}$ of optimal diluted monoclonal antibody FMC63 (anti-CD19, Flinders Medical Centre) for 30 minutes. After washing twice, the cells were then incubated with $50 \mu$ l of FITC-conjugated sheep antibody to mouse Ig $\mathrm{F}(\mathrm{ab})$ fragment (Silenus Laboratory, Victoria) for 30 minutes. Following washing and blocking using normal mouse serum, the cells were finally incubated with the $20 \mu \mathrm{l}$ of PElabelled anti-Leu-1 antibody (anti-CD5, Beckton Dickinson) for 30 minutes. The cells were then washed three times and fixed. Fluorescence analysis was carried out using
FACScan flow cytometer (Beckton Dickinson, Mountain View, California) with standard settings. The efficacy of gating of the lymphocyte population was checked by the monocyte marker CD14 (FMC33, Flinders Medical Centre). The monoclonal antibody X-63 (negative control for lymphocytes, Flinders Medical Centre), FMC16 (positive control for lymphocytes, Flinders Medical Centre), OKT 3 (Pan-T-cell marker, American Type Culture Collection) were also used for control. For staining of X63, CD14, FMC16, and OKT3, the cells were first incubated with $50 \mu \mathrm{l}$ of the optimal diluted monoclonal antibodies, and then incubated with $50 \mu \mathrm{l}$ of FITC-conjugated sheep antibody to mouse Ig $\mathrm{F}(\mathrm{ab})$ fragment (Silenus Laboratory, Victoria) as described above. Ten thousand cells were analysed from each sample. The results were stored and analysed in list mode of lysis II program. To further analyse if the fluorescence distribution was unimodal or bimodal, 10000 B cells were selected by live gating.

SECRETION OF LMW IgM IN VITRO

Cultures were established in 24 well flatbottomed $2 \mathrm{~mL}$ culture plate containing $1 \times 10^{6} \mathrm{PBMCs}$ or mononuclear cells from SF/ $\mathrm{mL}$ and pokeweed mitogen (PMW, Gibco, Ohio USA) at a final dilution of 1:800 with or without 2-mercapatoethanol (2-ME) at $10^{-4}$. Cultures were carried out in RPMI 1640 medium supplemented with penicillin $G(200$ $\mathrm{U} / \mathrm{mL})$, gentamicin $(10 \mathrm{mg} / \mathrm{mL})$, L-gutamine $(0.3 \mathrm{mg} / \mathrm{mL})$, and $10 \%$ fetal calf serum. The cells were incubated at $37^{\circ} \mathrm{C}$ in a humidified atmosphere of $5 \% \mathrm{CO} 2$ for three days, the supernatants collected, and then with fresh culture medium for further four days culture (two stages) or continuing seven days culture (without collecting the supernatants at day 3 ). The collected culture supernatants (total volume $20-30 \mathrm{ml}$ ) were concentrated in an Amicon ultrafiltration unit to a final volume of 300-400 $\mu \mathrm{L}$ for LMW IgM quantitation. At day 7 the cell viability was determined.

CD5 HYBRIDOMAS CULTURE SUPERNATANTS Culture supernatants from three CD5 positive hybridomas and two CD5 negative hybridomas were kindly provided by Dr C Brown (Division of Clinical Immunology, Kennedy Institute of Rheumatology, London). The hybridomas were established using in vivo activated B cells present in RA synovium immortalised by cell fusion using the heteromyeloma fusion partner, SPAZ-4. They all produced IgM. The supernatants (total volume $40-50 \mathrm{~mL}$ each) were concentrated in an Amicon ultrafiltration unit to a final volume 1-3 $\mathrm{mL}$ for further IgM size examination.

DETECTION OF LMW IgM

LMW IgM was detected by an enhanced chemiluminescence detection system combined with a modified immunoblot technique. ${ }^{21}$ In brief, serum and culture super- 


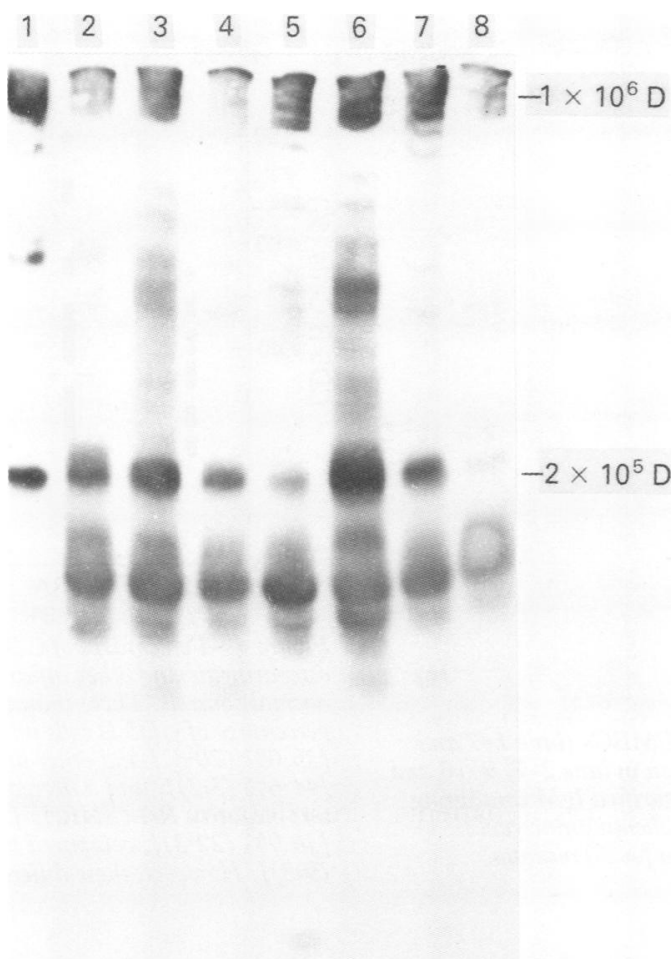

Figure 1 Immunoblot appearance of $R A$ sera containing variable levels of distinct monomeric IgM band $\left(2 \times 10^{5}\right.$ $\mathrm{Da})$; the majority of them also having dimeric, trimeric and other oligomeric IgM in addition to the pentameric band $\left(1 \times 10^{6} \mathrm{Da}\right)$. Lane 1 is a purified IgM containing both HMW IgM and LMW IgM as standard control.

natant was separated on $3 \cdot 6 \%$ SDS-PAGE and the separated serum proteins transferred to nitrocellulose, the IgM bands were developed with anti- $\mu$, HRP-conjugated secondary antibody (Silenus Laboratory, Victoria) and binding finally detected by the enhanced chemiluminescence detection system (Amersham, UK) over 30 seconds. After immunoblotting, the blot was scanned using a Camag electrophoresis scanner and the areas subtended by the LMW IgM peak weighted and expressed in mg quantities.

OTHER IMMUNOLOGICAL METHODS

Serum IgM, RF and $C$ reactive protein (CRP) were measured by laser nephelometry (Beckmans ICS). The interassay coefficients of variance for these measurements were $3 \cdot 8 \%$, $3 \cdot 3 \%$ and $3 \cdot 2 \%$, respectively.

STATISTICAL ANALYSIS

The liner correlation method was used for the analysis of any correlations between two variables. Comparison between patients and controls for LMW IgM and CD5 B cells were performed using the Student's $t$ test. Significance was accepted if $\mathrm{p}<0 \cdot 05$.

\section{Results}

LMW IgM IN THE SERA OF PATIENTS AND NORMAL CONTROLS

Sera from all patients and normal controls were examined for LMW IgM by the sensitive immunoblot method. In all patients' sera, distinct monomeric IgM bands were observed and in the majority of these dimeric, trimeric and other oligomeric IgM bands were also visible in addition to the pentameric band (fig 1). Among the patient groups, LMW IgM levels were significantly higher in sero-positive RA patients compared with sero-negative RA and other patients, $(\mathrm{p}<0.01)$ (table 1). In contrast, LMW IgM was detected only in low level or trace quantities in the sera from normal controls as compared with patient group (table 1 , the immunoblot for the normal controls not shown).

\section{IN VITRO STUDIES}

PBMC were prepared from 25 patients with RA, two with osteoarthritis and 12 normal controls. In addition, mononuclear cells from the SF from a patient with active RA was also used for in vitro studies. Using the immunoblot method, distinct LMW IgM bands were clearly revealed in the culture supernatants of 20 patients with RA and two patients with osteoarthritis whilst only four normal controls secreted trace amounts of monomeric and oligomeric IgM in addition to pentameric IgM (fig 2). Remarkably, LMW IgM accounted for $40 \cdot 1 \%$ of the total secreted IgM from mononuclear cells from SF. In these cell culture experiments cell viability at day 7 was $96 \%$ with no differences being observed between patients and controls. There was no significant correlation between amount of LMW IgM in the sera and supernatant $(r=0 \cdot 2, p>0 \cdot 05)$. Further studies found the addition of $2-\mathrm{ME}$ to the cultures in final concentrations of $10^{-4} \mathrm{M}$ resulted in the ocurrence of increased quantities of monomeric and oligomeric $\operatorname{IgM}$ in the culture supernatant (fig 3 ). We have previously shown that this low concentration of 2-ME does not directly reduce secreted pentameric IgM to monomeric state in-vitro using the same experimental conditions as described above. $^{22}$

Table 1 Serological and cellular indices in patients

\begin{tabular}{|c|c|c|c|c|c|}
\hline \multirow[t]{2}{*}{ Patients and controls } & \multicolumn{5}{|c|}{ Serological and cellular mean $(S D)$ indices } \\
\hline & $L M W I g M$ (mg weight) & Total $\operatorname{IgM}(g / L)$ & CD5 B cells \% & $R F^{\prime}$ & $C R P^{2}$ \\
\hline $\begin{array}{l}\text { Sero-positive RA }(n=31) \\
\text { Sero-negative RA }(n=7) \\
\text { Other inflammatory arthritides }(n=8) \\
\text { Osteoarthritis }(n=3) \\
\text { Normal controls }(n=17)\end{array}$ & $\begin{aligned} & 279 \cdot 3(147 \cdot 6) \\
& 85 \cdot 3(47 \cdot 5) \\
& 144 \cdot 4(131 \cdot 1) \\
& 116 \cdot 0(46 \cdot 7) \\
& 52 \cdot 4(28 \cdot 9)\end{aligned}$ & $\begin{array}{l}1.69(0 \cdot 79) \\
0.66(0.67) \\
1.38(0.62) \\
1.34(0.91) \\
1.53(0.82)\end{array}$ & $\begin{array}{l}35 \cdot 0(20 \cdot 3) \\
32 \cdot 2(10 \cdot 7) \\
41 \cdot 6(3 \cdot 2) \\
30 \cdot 9(22 \cdot 3) \\
33 \cdot 4(9 \cdot 3)\end{array}$ & $\begin{array}{l}365 \cdot 1(378 \cdot 8) \\
<30 \\
155 \cdot 0(231 \cdot 5) \\
35 \cdot 0(8 \cdot 6) \\
-\end{array}$ & $\begin{array}{r}24 \cdot 6(27 \cdot 0) \\
23 \cdot 9(35 \cdot 7) \\
9 \cdot 4(10 \cdot 7) \\
5 \cdot 0(2 \cdot 8) \\
-\end{array}$ \\
\hline
\end{tabular}

${ }^{1} \mathrm{RF}=$ Rheumatoid Factor, iu/mL $(\mathrm{N}<30)$

${ }^{2} \mathrm{CRP}=\mathrm{C}$ Reactive Protein, $\mathrm{mg} / \mathrm{L}(\mathrm{N}<6)^{1}$ 


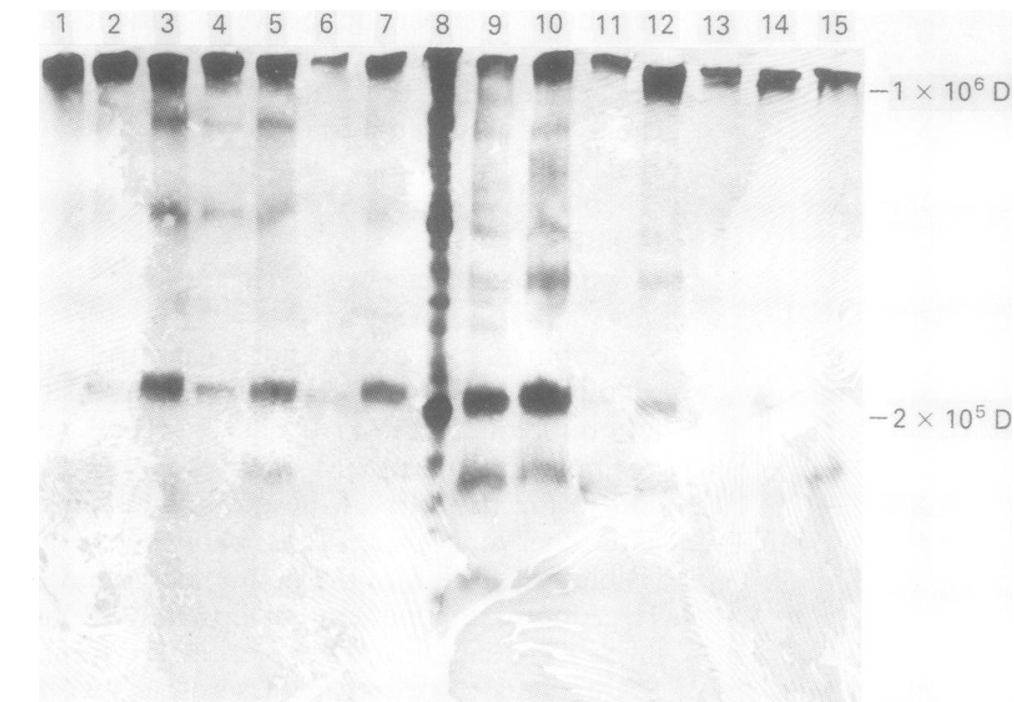

Figure 2 Immunoblot appearance of culture supernatants from PMBCs (lane 1-7 and 9-15). One distinct monomeric IgM band $\left(2 \times 10^{5} \mathrm{D}\right)$ can be seen in lane 2-7, 9-10 and 12 in addition to the pentameric band $\left(1 \times 10^{6} \mathrm{D}\right)$. Lane 8 is a purified IgM containing both HMW IgM and LMW IgM as standard control. Note: the chemiluminescence reaction was visualised by exposure of the NC to radiographic film for 30 minutes.

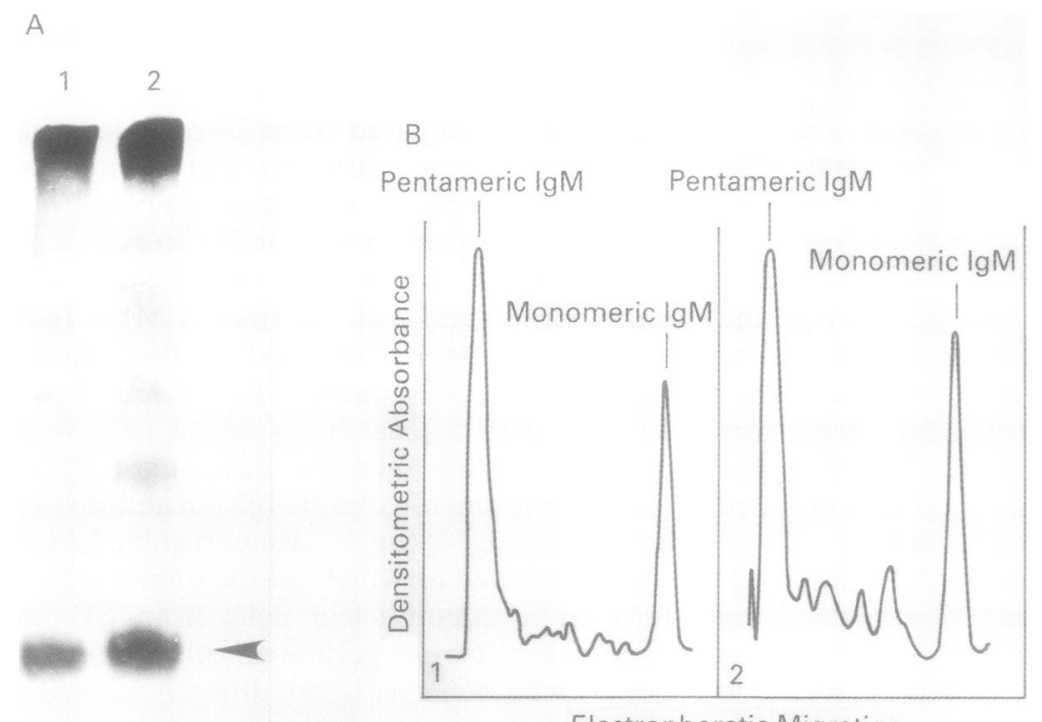

Electrophoretic Migration

Figure 3 (A) Immunoblot appearance of the supernatants from an in vitro study: 1) without 2-ME in culture medium; 2) with 2-ME in culture medium. An arrow indicates the band of LMW IgM. (B) Densitometric profiles of PBMC culture supernatants with corresponding to $A$. Enhanced secretion of $L M W I g M$ and other oligomeric IgM from $P B M C$ with 2-ME in culture medium was noted.

CD5 B CELLS IN RA AND NORMAL CONTROLS Using FACScan flow cytometry and twocolour fluorescence, CD5 B cells were enumerated in the PB of patients and controls. A comparison of the percentage of $\mathrm{CD} 5 \mathrm{~B}$ cell in the different study groups is shown in fig 4 . An increased mean (SD) percentage of CD5 B cells in sero-positive RA [35.0 (20.3)] and other inflammatory arthritides $[41.6(3.2)]$, and a decreased percentage in sero-negative RA $[32.2(10 \cdot 7)]$ and osteoarthritis [30.9 $(22 \cdot 3)$ ] was observed, when compared with normal controls $[33 \cdot 4(9 \cdot 3)]$. These differences however were not significant (table 1).

CD5 B cells were measured in eight patients with RA and two with other inflammatory

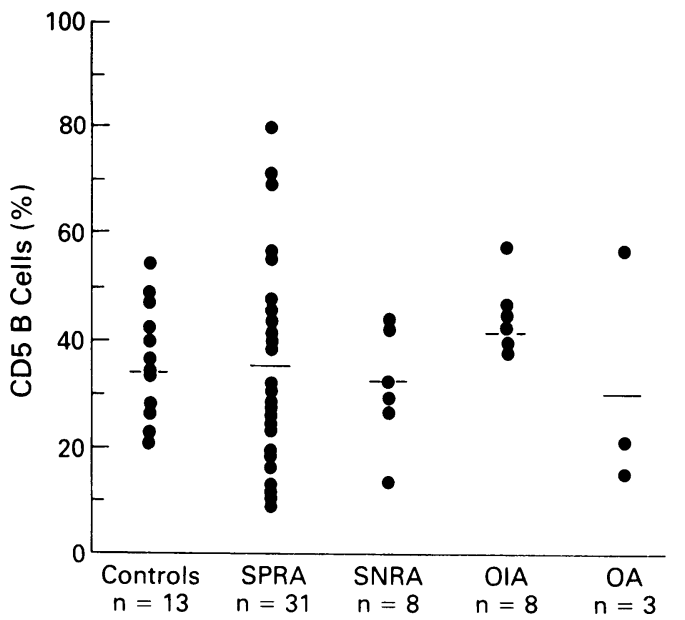

Figure 4 Percentages of $C D 5 B$ cells in patients with $R A$, osteoarthritis and other inflammatory arthritides and normal controls. There is an increased mean (SD) percentage of $C D 5 B$ cells in sero-positive $R A$ (SPRA)

$[35.0 \%(20 \cdot 3)]$ and other inflammatory arthritides (OIA) $[41.6 \%(3 \cdot 2)]$, and a decreased mean (SD) percentage in sero-negative RA (SNRA) [32.2\% (10.7)], osteoarthritis $[30 \cdot 9 \%(22 \cdot 3)]$, compared with normal controls $[33.4$ (9.3)]. However, these differences are not significant.

arthritides for more than two occasions over a one year period. CD5 B cells remained constant in these patients despite different disease activity or treatment regime (table 2). Studies of CD5 B cells in a small group of normal controls with different ethnic backgrounds, found that Chinese subjects had significantly higher levels than white subjects [41.2\% (10.6) v 33.4\% (9.3), $\mathrm{p}<0.01]$.

To analyse if the fluorescence distribution of the CD5 antigen was unimodal or bimodal, $10000 \mathrm{~B}$ cells were selected by live gating. It was shown that there were three populations of $\mathrm{B}$ cells, with the majority of $\mathrm{B}$ cells unstained, a small number of cells briefly stained for CD 5 and a few intermediate staining cells. There was a significant low level of highly stained CD5 B cells in RA compared with controls $(1 \cdot 7 \% v 4 \cdot 0 \%)$ (fig 5 ).

CORRELATION BETWEEN IMW IgM, CD5 B CELLS AND OTHER IMMUNOLOGICAL INDICES

Significant correlations were noted between LMW IgM and total IgM in RA (both seropositive and negative. $r=0.76, r=0.94$, $\mathrm{p}<0.05$, respectively), but not in patients with other inflammatory arthritides $(r=0.41$, $\mathrm{p}>0.05)$ and osteoarthritis patients $(r=0.46$, $p>0.05)$. Significant correlations were also observed in LMW IgM and RF in sero-positive RA ( $r=0.49, p<0.05$ ) (fig 6). However, there were no significant correlations between total IgM and CD5 B cells $(r=0.018, p>0.05)$, LMW IgM and CD5 B cells $(r=0, p>0.05)$, RF and CD5 B cells $(r=0, p>0.05)$, and CRP and CD5 B cells $(r=0.016, p>0.05)$ in Seropositive RA and all other patient groups (fig 6).

LMW IgM IN SUPERNATANTS FROM IgM SECRETING B CELL LINES

To explore the cellular origins of LMW IgM in RA, CD5 B cell lines were cultured and the 
Table 2 CD5 B cells in patients over time

\begin{tabular}{|c|c|c|c|c|c|c|c|}
\hline Patients & Sex/age & Diagnosis & Disease duration & Disease activity & Drug regime & Tested date & CD5 B cells\% \\
\hline 1 & $F / 71$ & SPRA & 20 years & $\begin{array}{l}\text { Active } \\
\text { Active }\end{array}$ & $\begin{array}{l}\text { Meth } \\
\text { None }\end{array}$ & $01 / 07 / 91$ & $\begin{array}{l}31.8 \\
32.2\end{array}$ \\
\hline 2 & $F / 60$ & SPRA & 39 years & Active & Meth & $\begin{array}{l}07 / 107 / 91 \\
01 / 07 / 91\end{array}$ & $\begin{array}{l}32 \cdot 2 \\
68 \cdot 6\end{array}$ \\
\hline 3 & $F / 71$ & SPRA & 10 years & $\begin{array}{l}\text { Active } \\
\text { Active } \\
\text { Active }\end{array}$ & $\begin{array}{l}\text { Meth } \\
\text { Imuran/Pred } \\
\text { Pred }\end{array}$ & $\begin{array}{l}09 / 09 / 91 \\
15 / 07 / 91 \\
11 / 1 / 91\end{array}$ & $\begin{array}{l}70 \cdot 7 \\
25 \cdot 8 \\
23.9\end{array}$ \\
\hline 4 & $F / 29$ & SPRA & 4 years & Active & Pred/Plaq & $\begin{array}{l}1111191 \\
21 / 10 / 91 \\
16 / 0302\end{array}$ & $\begin{array}{l}23.9 \\
40 \cdot 6\end{array}$ \\
\hline 5 & $\mathrm{~F} / 59$ & SPRA & 18 years & Active & None & $09 / 03 / 92$ & $40 \cdot 1$ \\
\hline 6 & $F / 81$ & SPRA & $>10$ years & $\begin{array}{l}\text { Active } \\
\text { Inactive } \\
\text { Active }\end{array}$ & $\begin{array}{l}\text { Gold/Plaq/Pred } \\
\text { None } \\
\text { Pred }\end{array}$ & $\begin{array}{l}15 / 06 / 92 \\
04 / 05 / 92 \\
06 / 07 / 92\end{array}$ & $\begin{array}{r}31 \cdot 2 \\
10 \cdot 9 \\
9 \cdot 8\end{array}$ \\
\hline 7 & $M / 62$ & SPRA & 6 years & $\begin{array}{l}\text { Acuve } \\
\text { Active } \\
\text { Active }\end{array}$ & $\begin{array}{l}\text { None } \\
\text { Meth }\end{array}$ & $\begin{array}{l}04 / 05 / 92 \\
06 / 07 / 92\end{array}$ & $\begin{array}{l}9.8 \\
30 \cdot 4 \\
25 \cdot 5\end{array}$ \\
\hline 8 & M/69 & SNRA & 8 years & $\begin{array}{l}\text { Active } \\
\text { Inactive }\end{array}$ & Meth & $08 / 07 / 91$ & $\begin{array}{l}23.3 \\
28.9\end{array}$ \\
\hline 9 & $F / 88$ & OIA & 1 year & $\begin{array}{l}\text { Active } \\
\text { Inactive }\end{array}$ & Sala/Pred & $01 / 07 / 91$ & $\begin{array}{l}57.5 \\
38.8\end{array}$ \\
\hline 10 & $M / 24$ & OIA & 5 years & $\begin{array}{l}\text { Inactive } \\
\text { Active } \\
\text { Active }\end{array}$ & $\begin{array}{l}\text { None } \\
\text { Plaq } \\
\text { Thyroxine }\end{array}$ & $\begin{array}{l}04 / 11 / 91 \\
15 / 07 / 91 \\
04 / 11 / 91\end{array}$ & $\begin{array}{l}38.8 \\
47 \cdot 2 \\
45 \cdot 0\end{array}$ \\
\hline
\end{tabular}

SPRA: Sero-positive RA; SNRA: Sero-negative RA; OIA: Other inflammatory arthritides, Meth: Methotrexate; Imuran: Azathioprine; Pred: Prednisone; Plaq: Plaquenil; Sala: Salazopyrin.

supernatants examined for IgM size. It was shown that LMW IgM could be detected in the supernatants from both CD5+ and CD5- B cell lines (fig 7).

\section{Discussion}

Using our sensitive chemiluminescence detection system we have shown that LMW IgM existed in all our patients with RA and significant higher levels was found in the seropositive patients (fig 1, table 1). Furthermore, a significant correlation was noted between LMW IgM and RF in these patients (fig 6).

The significance of LMW IgM in these sera is unknown. LMW IgM has been detected in both sera and SF of the patients with RA but not SF from other inflammatory arthritides. $^{2}{ }^{23} 24$ Anderson-Imbert ${ }^{23}$ reported that the concentrations of LMW IgM in SF always exceeded that of the corresponding sera, but Roberts-Thomson et $a l^{2}$ found that only two of 10 RA SF had higher LMW IgM levels than the corresponding sera, implying the local synovial membrane synthesis of LMW IgM. This is confirmed in our in vitro study which showed that secreted LMW IgM was found from mononuclear cells from the $S F$ of a patient with RA and the amount of LMW IgM accounted for $40 \cdot 1 \%$ of the total secreted IgM. This finding provides direct evidence that LMW IgM can be synthesised in pathogenic joints.

The mechanism(s) for the occurrence of LMW IgM in human disease are still uncertain. Previous reports clearly showed that LMW IgM was not the product of pentameric IgM metabolism in vivo and not derived from membrane-bound IgM as well. ${ }^{4}$ In this study we found a significant correlation between the levels of circulating LMW IgM and total IgM (fig 6); the presence of LMW IgM with other LMW oligomers of IgM (fig 1); and the secretion of LMW IgM from PBMC in vitro (fig 2). All these findings suggest that $\mathrm{LMW}$ IgM may be released into circulation due to a defect of assembly of the IgM pentameric molecule. This could be a deficiency in any of the multiple steps involved in IgM polymerisation. However, in these steps J chain and glycosylation of $\mu$ heavy chain is not required for IgM polymerisation, per se. ${ }^{25}$ In this study we showed the addition of low quantities of $2-\mathrm{ME}$ to the culture medium could enhance
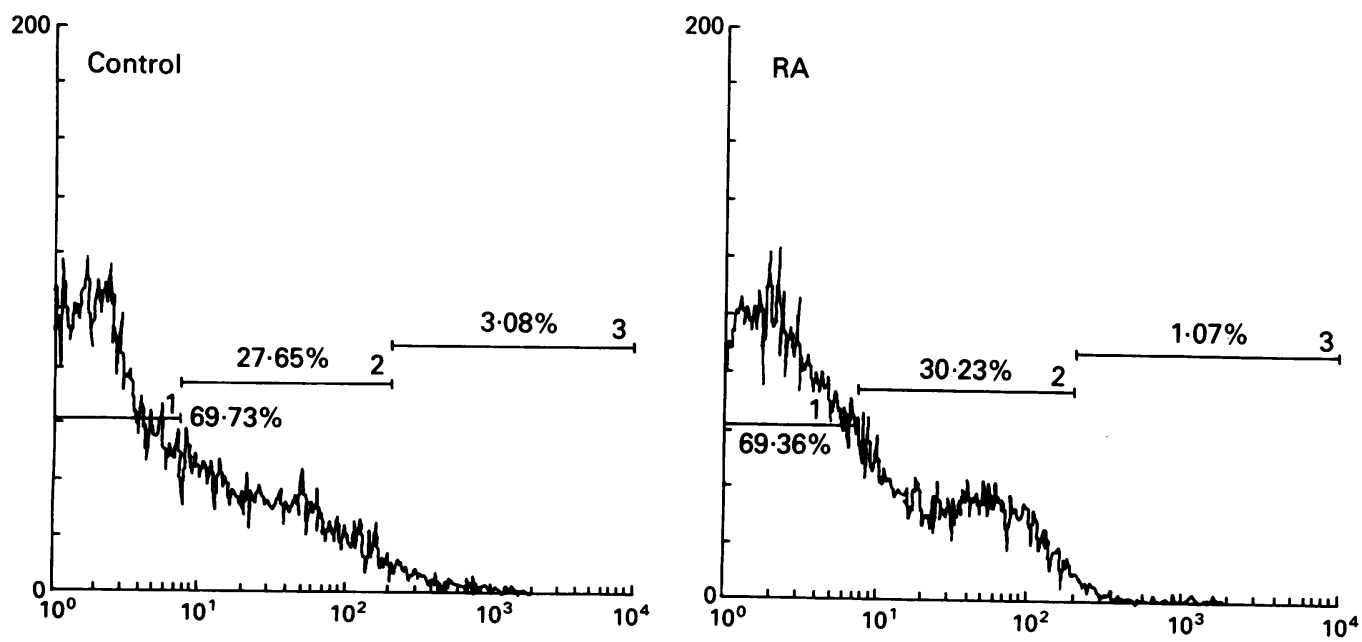

Fluorescence intensity

Figure 5 Histogram depicting $B$ cells (selected using anti-CD19 staining together with forward and side-scatters) staining with CDS antibody. Three populations of CD5 B cells were observed. There was a significant low level of highly stained $C D 5 B$ cells in $R A$ compared with controls (1.7\% v $4.0 \%)$. 

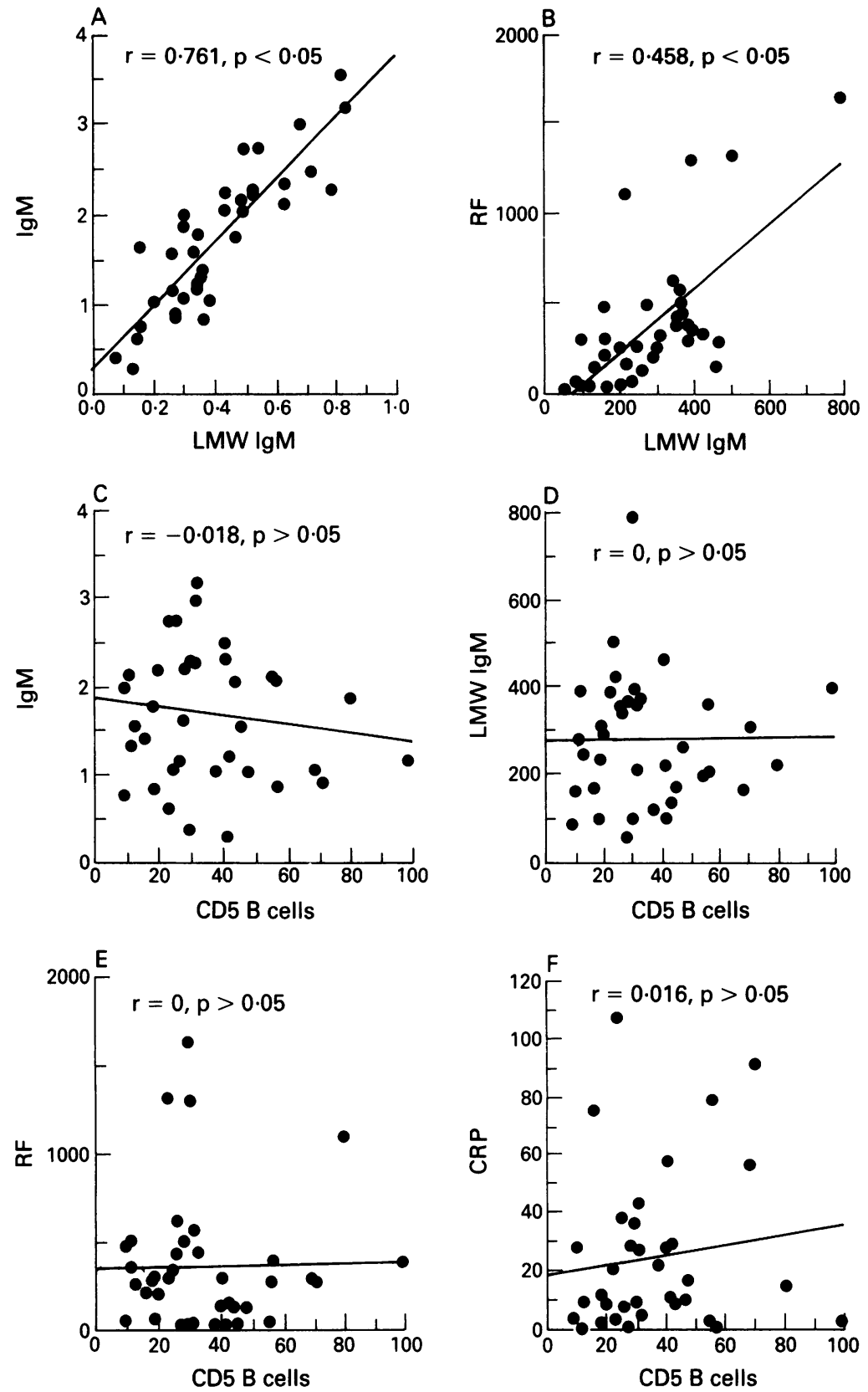

Figure 6 Correlations between LMW IgM, CD5 B cells and other immunological indices in sero-positive RA. Significant correlations were noted only between LMW IgM and total $\operatorname{IgM}(A: r=0.76, p<0.05)$, and $L M W \operatorname{IgM}$ and $R F(B: r=0.46, p<0.05)$. There were no significant correlations between total IgM and CDS B cells (C: $r=-0.018, p>0.05)$, LMW IgM and CD5 B cells (D: $r=0, p>0.05$ ), RF and CDS $B$ cells ( $E: r=0, p>0.05$ ), and CRP and CD5 $B$ cells ( $F: r=0.016, p>0.05)$.

the secretion of LMW IgM from PBMC in vitro (fig 3). Our more recent experiment using a JVM3 cell line and others using a $\mathrm{B}$ lymphoma cell line have observed the same finding. ${ }^{22} 26$ This raises the possibility that alteration in the redox potential of the cellular microenvironment or the provision of free-SH radicals which might interrupt interchain disulphide bonds might be important. It is known that IgM polymerisation is catalysed by two protein enzymes-protein disulphide isomerase and protein disulphide oxidoreductase. ${ }^{27}{ }^{28}$ Protein disulphide isomerase has multiple roles in the modification of nascent secretory proteins. ${ }^{27}$ Protein disulphide oxidoreductase, on the other hand, is identified to be a $B$ lymphocyte specific enzyme that catalyses pentamer IgM assembly. ${ }^{28}$ The addition of $2-\mathrm{ME}$ to the culture medium could

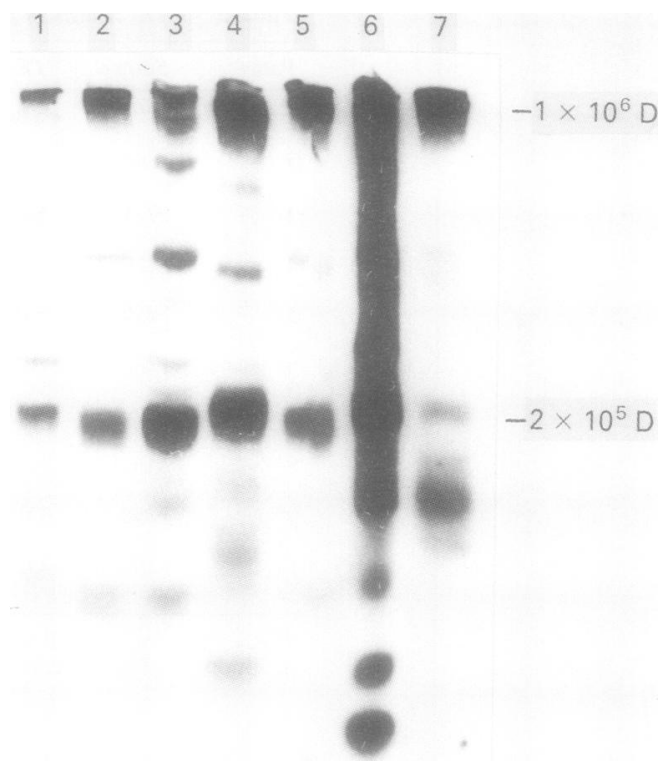

Figure 7 LMW IgM in CD5+ and CD5- $B$ cell line culture supernatants. Lane $1-3$ are $C D 5+$ cell lines culture supernatants. Lane 4-5 are CD5-cell lines culture supernatants. Lane 6 is a positive control serum. Lane 7 is a normal human serum. LMW IgM could be detected in the supernatants from both $C D 5+$ and $C D 5-B$ cell lines.

interfere with the functional activity of this enzyme or the sulphydryl radicals of the cysteine involved in inter-chain disulphide links. It is found that cysteine in $\mu$ tailpiece plays a crucial role in the polymerisation of IgM. ${ }^{29}$ Thus molecular cloning and the characterisation of disulphide oxidoreductase should ultimately shed some insight into the gene regulation of polymerisation of $\operatorname{IgM}$ and provide basic insights into the mechanism underlying development and differentiation of $B$ lymphocytes in human disease.

Whether LMW IgM is derived from a specific subset of B lymphocytes has not been previously explored. We therefore focused our investigation on CD5 B cells. Previous studies have found that LMW IgM commonly occurs in four disease groups. ${ }^{4}$ Coincidentally, in these diseases there invariably exist higher levels of circulating CD5 B cells or activated CD5 B cells. ${ }^{141617192130}$ CD5 B cells are responsible for the production of high affinity RF in RA. ${ }^{15}$ Futhermore, LMW IgM and CD5 $B$ cells from patients with RA shared the same major RF cross-reactive idiotype. ${ }^{31}$ These data indirectly suggest that LMW IgM may come from CD5 B cells. However, in this study no significant correlation was found between LMW IgM and CD5 B cells in patients with RA (fig 6). In vitro study showed that variable levels of LMW IgM could be detected in PBMC from the majority of patients with RA. Furthermore, LMW IgM could be detected in the supernatants from both CD5+ and CD5B cell lines (fig 7). This study therefore suggests that LMW IgM is unlikely to be derived solely from CD5 B cells. 
We also addressed the question of the role of CD5 $B$ cells in RA. We found increased percentages of CD5 B cells in RA (fig 4), however, these differences were not significant compared with healthy controls (table 1). The increased frequency of CD5 B cells in RA blood was initially reported by Plater-Zyberk et $a l$, in $1985^{13}$ and observed by others, ${ }^{915} 1732$ but not all reports have confirmed these findings. ${ }^{33}$ These controversial results may be due to a number of reasons, including the wide differences in the epitope density of CD5 on the $\mathrm{B}$ cell membrane, patient sampling, drug regime, and the different sensitivities of the methods used. Our study found different epitope density of $\mathrm{CD} 5$ on the B cells with three populations of CD5 $\mathrm{B}$ cells being observed (fig 5). The significance of this bimodal fluorescence distribution in CD5 B cells is unknown but it appeared that the increased CD5 $\mathrm{B}$ cells in RA are the intermediate staining cells. Methods with different sensitivities for the detection of CD5 B cells give rise to the different levels of $\mathrm{CD} 5 \mathrm{~B}$ cells in the circulation. For example, using fluorescence-microscopic techniques, CD5 B cells were found to comprise an average of $20 \%$ of the circulating $B$ cells of patients with $R A$ compared with less than $5 \%$ of the B cells of normal controls. ${ }^{13}$ However, Dauphine et al, using a sensitive flow-cytometric technique, reported that $46 \%$ of rheumatoid B cells were CD5 positive compared with $20 \%$ CD5 B cells in normal controls. ${ }^{35}$ Another report showed the control group of individuals in which the proportions of CD5 B cells rose from $<5 \%$ when detected by microscopy to $19 \cdot 5 \%$ when identified by the FACstar cytometry. ${ }^{36}$ In comparative evaluation CD5 $\mathrm{B}$ cells in RA patients using FACS analyser and FACScan, different levels of CD5 B cells have been found in the same patient's sample. ${ }^{37}$ As such, more sensitive techniques have resulted in smaller differences in the proportions of CD5 B cells in RA and normal controls.

Our data showed the levels of CD5 B cells in the PB of patients with RA and other inflammatory arthritides were stable over time (table 2). This finding has been supported by other investigations. ${ }^{1638} 39$ The exception was patients treated with high-dose corticosteroids or combined immunosuppressive chemotherapy and irradiation. ${ }^{16}{ }^{39}$ However, there appears to be no clear correlation between the numbers of CD5 B cells and the therapy. ${ }^{40}$ The increase of CD5 B cells also appears to be independent of disease activity in juvenile arthritis. ${ }^{41}$ The proportion of circulating B cells that express CD5 appears to be relatively constant in any given individual. ${ }^{38} \mathrm{~A}$ recent study found that elevated levels of CD5 B cells were a distinctive feature of selected families with RA, rather than a peculiarity of patients with RA compared with their healthy relatives. ${ }^{32}$ Moreover, monozygotic twins discordant for RA have identical levels of CD5 $B$ cells. ${ }^{38}$ Thus these data suggest that the expression of $\mathrm{CD} 5$ on $\mathrm{B}$ cells, within the framework of RA is, at least partly, genetically determined. This conclusion is further supported by our finding that CD5 B cells are higher in certain ethnic groups such as Chinese. This finding is consistent with another report that Japanese have elevated levels of CD5 B cells. ${ }^{42}$

In the present study no significant correlations were observed between CD 5 B cells and other immunological indices including RF (fig 6). Several studies have also shown no apparent relationship between the relative CD5 $\mathrm{B}$ cell levels and the titre of $\mathrm{RF}^{13}{ }^{38}$ except for patients with extremely high titres $\left(>5 \times 10^{12}\right)$ of $R F .{ }^{39}$ Moreover, not all patients with RA have high levels of CD5 B cells, and normal unaffected individuals without RF may have high levels of CD5 B cells. ${ }^{17} 3843$

What is the role of CD5 B cells in the pathophysiology of RA? The answer is still uncertain. Perhaps these uncertainties are secondary to the fact that the population of circulating lymphocytes in the PB is not representative of the cells found at sites of primary disease activity such as the peripheral joints. A study has already demonstrated that percentages of CD5 B cells in patients with RA were significantly higher in SF compared with that in PB. ${ }^{33}$ A closer examination of the cells and autoantibodies secreted within these sites may therefore reveal a more definitive relationship between the $\mathrm{CD} 5 \mathrm{~B}$ cells and autoimmune diseases.

Dr Huji Xu is an Australian National Health and Medical Research Council (NH\&MRC) Visiting and Postgraduate Scholar. This work is supported by grants from the Arthritis Foundation of Australia and NH and MRC for the scholarship.

1 Harisdangkul V, McDougal J S, Knapp M, Christian C L. Naturally occurring low molecular weight IgM in patients with rheumatoid arthritis, systemic lupus erythematous and macroglobulinemia. I. Purification and immunologic studies. F Immunol 1975; 115: 216-22.

2 Roberts-Thomson $\mathrm{P} J$, Wernick $\mathrm{R} M$, Ziff $M$. Low molecular weight $\operatorname{IgM}$ in rheumatoid arthritis and other rheumatic diseases. Arthritis Rheum 1981; 24: 795-802.

3 Harris R, Beckman I, Roberts-Thomson. Low molecular weight IgM: detection using immunoblotting. F Immunol Methods 1986; 88: 97-100.

$4 \mathrm{Xu} \mathrm{H} \mathrm{J}$, Roberts-Thomson P J. Circulating low molecular weight IgM-A disease marker in autoimmune, infective, immunodeficient and B cell lymphoproliferative disorders. Disease Markers 1992; 10: 115-41.

5 Harisdangkul V, Barnes T Y, Sogcharoen S, Pennebaker J B. Clinical significance of low molecular weight IgM in patients with systemic lupus erythematous. $\mathcal{F}$ Rheumatol 1984; 11: 638-43.

6 Fakunle Y M, Aranguibel F, DeViliers D, Thomas H C, Slerlock S. Monomeric (7s) IgM in chronic liver diseases. Clin Exp Immunol 1979; 38: 204-10.

7 Koh L Y, Jones D N, Roberts-Thomson P J. Appearance of low molecular weight IgM during course of infective endocarditis. Clin Exp Immunol 1986; 64: 471-5.

8 Kwitko A, Roberts-Thomson P J, Shearman D J C. Low molecular weight IgM in selective IgA deficiency. Clin Exp Immunol 1982; 50: 198-202.

9 Kipps T J. The CD5 B cell. Adv Immunol 1989; 47: $117-85$.

10 Ledberter J A, Clark E A. Surface phenotype and function of tonsillar germinal center and mantle zone $B$ cell of tonsillar germinal center and mantle

11 Bofill M, Janossy G, Janossa M, et al. Human B cell development II. Subpopulations in the human fetus. Immunol 1985; 134: 1531-38.

12 Antin J H, Emerson S G, Martin P, Gadol N, Adult K A Leu-1+ $(\mathrm{CD} 5+)$ B cell. A major lymphoid subpopulation in human fetal spleen: Phenotype and functional studies. f Immunol 1986; 136: 505-10.

13 Plater-Zyberk C, Maini R N, Lam K, Kennedy T D, Janossy G. A rheumatoid arthritis B cell subset expresses phenotype similar to that in chronic lymphocytic leukemia. Arthritis Rheum 1985; 28: 971-6.

14 Lydyard P M, Youinou P Y, Cooke A. CD5-positive cells in rheumatoid arthritis and chronic lymphocytic in rheumatoid arthritis and chron

15 Burastero S E, Cassali P, Wider R L, Notkins A L Monoreactive high affinity and polyreactive low affinity rheumatoid factors are produced by $\mathrm{CD} 5+\mathrm{B}$ cells from patients with rheumatoid arthritis. $\mathcal{F}$ Exp Med 1988; 168: patients with 
16 Dauphinee $M$, Tovar Z, Talal N. B cells expressing CD5 are increased in Siogren's syndrome. Arthritis Rheum 1988; 31: $642-7$

17 Hardy R R, Hayakawa K, Shimizu M, Yamasaki K, Kishmoto T. Rheumatoid factors secretion from human Leu-1 + B cells. Science 1987; 236: 81-3.

18 Casali P, Burastero S, Nakamura M, Inghirami G, Notkins A L. Human lymphocytes making rheumatoid factors and antibodies to single stranded DNA belong to the Leu-1+B cell subset. Science 1987; 236: 77-81.

19 Casali P, Notkins A L. Probing the human B -cell repertoire with EBV: polyreactive antibodies and $\mathrm{CD} 5+\mathrm{B}$ lymphocytes. Ann Rev Immun 1988; 7: 513-35.

20 Casali P, Burastero S, Balow J E, Notkins A L. High-affinity antibodies to ssDNA are produced by $\mathrm{CD} 5 \mathrm{~B}$ cells in antibodies to SsDNA are produced by CD5 B cells in systemic lupus

21 Xu H J, Umapathysivam K, McNeilage J, Gordon T P Roberts-Thomson P J. An enhanced chemiluminescence detection system combined with a modified immunblo technique for the detection of low molecular weight $\operatorname{IgM}$ in sera from healthy adults and neonates. $\mathcal{F}$ Immunol Methods 1992; 146: 241-7.

22 Xu H J, Roberts-Thomson P J. Low molecular weight IgM in the sera of patients with chronic lymphocytic leukemia. Pathology 1993; 25: 52-6.

23 Anderson-Imbert A, Harisdangkul V, Debracco $M$ Christian C L. Low molecular weight IgM in rheumatoid synovial fluid. Arthritis Rheum 1972; 15: 426.

24 Ezaki I, Shingu M, Nobunaga M, Otsuka E. Detection of low molecular weight IgM by immunoblot analysis in rheumatoid arthritis. 7 Rheumatol 1987; 14: 674-9.

25 Davis A C, Shulamn M J. IgM-Molecular requirements for its assembly and function. Immunol Today 1989; 10: 118-28.

26 Alberini C M, Bet P, Mistein C, Sitia R. Secretion of immunoglobulin $M$ assembly intermediates in the immunoglobulin $M$ assembly intermediates in the

27 Freedman R B. Protein disulfide isomerase: multiple role in Freedman R B. Protein disulfide isomerase: multiple role in
the modification of nascent secretory proteins. Cell 1989; 57: $1069-72$

28 Roth R, Koshland M E. Identification of a lymphocyte enzyme that catalyses pentamer immunoglobuin $M$ assembly. F Bio Chem 1981; 256: 4633-9.

29 Sita R, Neuberger M, Alberini C, et al. Developmental regulation of $\operatorname{IgM}$ secretion: the role of the carboxyterminal cysteine. Cell 1990; 60: 781-90.

30 Suzuki N, Sakene T, Engieman. Anti-DNA antibody production of CD5+ and CD5- B cells of patients with systemic lupus erythematous. 7 Clin Invest 1990; 85: 238-47.
31 Bongura V R, Pernis B, Agostino N, llowite N T, Hatam $\mathrm{L}$, Wedgwood $\mathrm{J} \mathrm{R}$. The major rheumatoid factor crossreactive idiotype in

32 Youinou $\mathrm{P}$, Mackenzie L, Katskis $\mathrm{P}$, et al. The relationship between CD5-expressing B lymphocytes and serologic abnormalities in rheumatoid arthritis and their relatives. Arthritis Rheum 1990; 33: 339-48.

33 Sowden J A, Roberts-Thomson P J, Zola H. Evaluation of CD55-positive B cells in blood and synovial fluid of patients with rheumatic diseases. Rheumatol Int 1987; 7: 255-9.

34 Smalley H B, Todd J, Barnes R M, Thompson R N, Abraham $G$ N, Jonson P M. Estimation of serum V Kappa III light chains in rheumatoid arthritis and Kappa III light chains in rheumatoid arthritis and 1990; 29: 325-30.

35 Dauphinee M, Kincaid W, Talal N. Increased incidence of $B$ cells coexpressing a $T$ cells marker in rheumatoid arthritis. Sixth International Congress of Immunology (abstr) $3,12,9$.

36 Plater-Zyberk C, Maini R N. Phenotypic and functional features of $C D 5+B$ lymphocytes in rheumatoid arthritis. Scand f Rheumatol 1988; 75 (suppl): 73-83.

$37 \mathrm{Xu} \mathrm{H} \mathrm{J}$, Roberts-Thomson P J, Ahern M J, Zola $\mathrm{H}$. Comparative evaluation of CD5 B cells in patients with rheumatoid arthritis and essential mixed rheumatoid arthritis and essential mixed cryoimmunoglobulinemia using FACS analyzer and
FACScan flow cytometer. Ann NY Acad Sci 1992; 651: FACScan

38 Kipps T J, Vaughan J H. Genetic influence on the levels of circulating CD5 B lymphocytes. F Immunol 1987; 139: 1060-4.

39 Taniquchi O, Miyajima $\mathrm{H}$, Hirano $\mathrm{T}$, et al. The Leu-1 B cell subpopulation in patients with rheumatoid arthritis. f Clin Immunol 1987; 7: 441-8.

40 MacKenzie M R, Paglieroni T G, Warner N L. Multiple myeloma: An immunological profile. IV. The EA rossetteforming cell is a Leu-1 positive

41 Martini A, Massa M, De Benedetti F, Viola S, Neirotti G, Burgio R G. CD5 positive B lymphocytes in seronegative juvenile arthritis. $\mathcal{F}$ Rheumatol 1990; 17: 932-5.

42 Hardy R R, Hayakawa K. Development and Physiology of Ly-1 B and its human homology Leu-1 B. Immunol Rev 1987; 93: 53-81.

43 Maini R N, Plater-Zyberk C, Andrew E. Autoimmunity in rheumatoid arthritis. An approach via a study B lymphocytes. Rheum Dis Clin North Am 1987; 13: 319-38. 